\title{
Reduction Behaviors of Hot Metal Dephosphorization Slag in a Slag Regenerator
}

\author{
Minoru ISHIKAWA \\ Corporate Research \& Development Laboratories, Sumitomo Metal Industries, Ltd., 16-1 Sunayama, Kamisu-City, Ibaraki 314- \\ 0255 Japan.
}

(Received on October 25, 2005; accepted on January 26, 2006)

\begin{abstract}
The reduction behavior of dephosphorization slag on the iron bath in the reduction furnace of the slag regeneration process was researched by test converter experiments. Dephosphorization slag and coke as the reduction agent and the heat source were added to the hot metal in the converter and oxygen was blown through the top lance. During the blowing, the reduction of $\left(\mathrm{P}_{2} \mathrm{O}_{5}\right),(\mathrm{FeO})$ and $(\mathrm{MnO})$ in the slag proceeded simultaneously. The amount of phosphorus and manganese oxide in the slag decreased and the amount of phosphorus and manganese in the metal increased in turn during the reduction. The unknown amount of these elements which occupied about $20 \%$ of total input also existed. The unknown parts of phosphorus and manganese in material balance are seemed to be caused mainly by the vaporization of phosphorus and manganese from the droplets generated by the reduction at the slag/coke interface.
\end{abstract}

KEY WORDS: slag regeneration process; hot metal dephosphorization; reduction; vaporization; regular solution model.

\section{Introduction}

The hot metal dephosphorization process, which is a simple refining process $(\mathrm{SRP})^{1,2)}$ is being operated in Sumitomo Metal Industries Ltd. In this process, two converter vessels are used as a dephosphorization furnace and a decarburization furnace as shown in Fig. 1. As dephosphorized hot metal is charged to decarburization furnace, the slag formed in the furnace contains less phosphorus oxide and is recycled to a dephosphorization furnace. In the dephosphorization furnace, no burnt lime other than lime contained in the recycled decarburization furnace slag is added.

Consequently, no decarburization furnace slag is emitted outside of the process. On the other hand, the dephosphorization furnace slag has not been used for high grade applications due to its physical properties and impurities. Also valuable elements in the dephosphorization slag such as phosphorus, manganese and iron are not recovered in the process. An improvement of the process efficiency and decreasing the cost may be expected if the dephosphorization slag is used for more valuable application and valuable elements in the dephosphorization slag are recovered.

With the aim of upgrading the use of the dephosphorization slag and recovering valuable elements, Li et al. proposed a slag regeneration process ${ }^{3)}$ in which the dephosphorization slag was reduced in the iron bath type reduction furnace to recover phosphorus, iron and manganese and high phosphorus hot metal produced in the process was dephosphorized to form high phosphorus dephosphorization slag for the use of fertilizer. In the work of Li et al., the slag regeneration process was proved to be realized by investi- gating slag and metal distribution ratios of reduced elements, heat and material balances in dephosphorization furnace, reduction furnace and decarburization furnace. However, the reduction behaviors of each elements in the reduction furnace have not been investigated.

Shiomi et $a l^{4)}$ researched the process in which liquid $\mathrm{CaO}-\mathrm{SiO}_{2}-\mathrm{P}_{2} \mathrm{O}_{5}$ based synthetic slag and basic oxygen furnace slag were reduced to recover iron and phosphorus in $\mathrm{Fe}-\mathrm{P}-\mathrm{C}$ based liquid alloy and after that silicon was added to the alloy to remove phosphorus as vapor. However, slag phase not in contact with metal bath was reduced by carbon in the work, and the behavior of slag reduction on the metal bath was not researched.

In this work, focusing the reduction behavior of dephosphorization slag on the iron bath in the reduction furnace, the slag regeneration process was researched with test converter experiments.

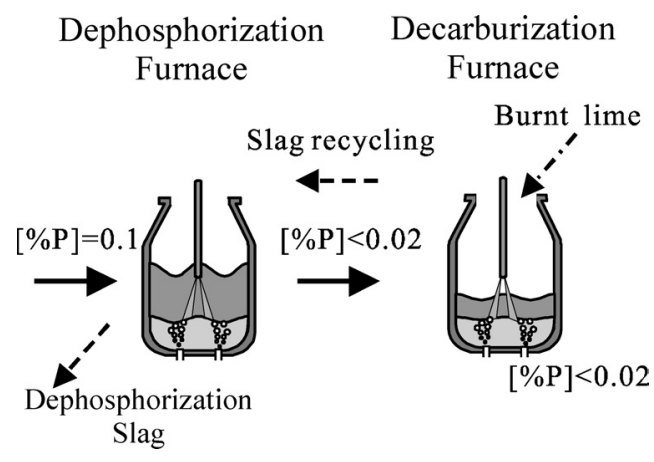

Fig. 1. Outline of the simple refining process (SRP). 


\section{Outline of the Slag Regeneration Process}

Figure 2 illustrates the slag regeneration process. ${ }^{5)}$ Hot metal dephosphorization slag is charged to the slag regenerator to be reduced with carbon from coke and with hot metal. Phosphorus, manganese and iron oxides in the dephosphorization slag are recovered in the hot metal. The reduced dephosphorization slag can be used for high grade applications or be used as a recycled slag in a dephosphorization furnace and so on. The hot metal in the slag regenerator can be used several times repeatedly as a metal bath for the reduction of the dephosphorization slag though its phosphorus and manganese contents gradually increase.

When the phosphorus content in the hot metal rises to about $1 \%$, it is dephosphorized in a final dephosphorization period to produce a slag containing about $15 \%$ phosphorus oxide and hot metal containing about $0.1 \%$ phosphorus. The hot metal after the final dephosphorization can be used again as a metal bath for the reduction period of a hot metal dephosphorization slag. So the hot metal in the slag regenerator is used several times repeatedly as a metal bath for both the reduction and the final dephosphorization period.

\section{Experimental Method}

Hot metal dephosphorization slag reduction experiments were done in the test converter. Hot metal dephosphorization slag with chemical composition shown in Table 1 was used. Experimental condition is shown in Table 2. Two experiments were done using different initial $[\mathrm{P}]$ and $[\mathrm{Mn}]$ content hot metal. In Test-1, low initial [P] and [Mn] content hot metal was used assuming initial stage of reduction. On the other hand, in Test-2, high initial [P] and [Mn] con-

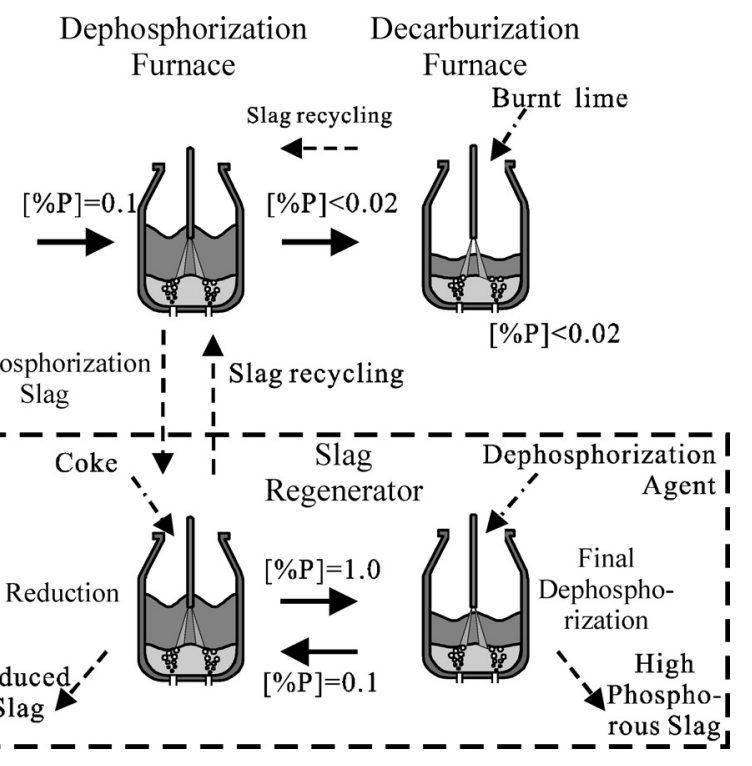

Fig. 2. Outline of the slag regeneration process. tent hot metal expected after repeated reduction practice was used. After charging with hot metal, dephosphorization slag and coke as reduction agent and heat source were added to the hot metal in the converter and oxygen was blown through the top the top lance. During the blowing, additional dephosphorization slag and coke were charged to reduce $\left(\mathrm{P}_{2} \mathrm{O}_{5}\right),(\mathrm{FeO})$ and $(\mathrm{MnO})$ in the slag.

\section{Experimental Results and Discussion}

\subsection{Behaviors of Slag and Metal Composition during the Reduction}

Two reduction experiments were done in this study. One was performed using low phosphorus and manganese content hot metal assuming the early stage of reduction as Test1. The other was performed using high phosphorus and manganese content hot metal assuming the later stage of reduction after repeated reduction blowing as Test-2. Behaviors of slag and metal elements in Test- 1 and Test-2 are shown in Figs. 3 and $\mathbf{4}$ respectively. As shown in Fig. 3, at the initial stage of about $10 \mathrm{~min}$ in each experiment, temporary decrease of phosphorus and manganese content occurred. After that, $\left(\mathrm{P}_{2} \mathrm{O}_{5}\right)$ in the slag decreased to less than $1 \%,(\mathrm{MnO})$ and $(\mathrm{FeO})$ in the slag decreased to less than $3 \%$ by 60 min.s blowing in Test-1. Phosphorus contents in hot metal increased to about $0.16 \%$ during the blowing in Test1. As shown in Fig. 4, $\left(\mathrm{P}_{2} \mathrm{O}_{5}\right)$ and $(\mathrm{FeO})$ in the slag decreased to less than $1 \%$ and $(\mathrm{MnO})$ in the slag decreased to less than $4 \%$ by 120 min.s blowing in Test-2. Phosphorus contents in hot metal increased to about $0.9 \%$ during the blowing in Test-2.

From the results mentioned above, recovery of phosphorus and manganese oxide in the hot metal dephosphorization slag was proved to be possible by carbon reduction.

\subsection{Material Balance of Phosphorus and Manganese}

Material balance of phosphorus and manganese in Test-1 and Test-2 was calculated. The amount of phosphorus and manganese in the slag was calculated by the slag amount estimated by $\mathrm{CaO}$ balance and analysis of $\mathrm{P}_{2} \mathrm{O}_{5}$ and $\mathrm{MnO}$.

Table 2. Experimental conditions.

\begin{tabular}{|c|c|c|c|c|}
\hline \multicolumn{3}{|c|}{ Test No. } & Test-1 & Test-2 \\
\hline \multirow{6}{*}{$\begin{array}{l}\text { Hot } \\
\text { metal }\end{array}$} & \multicolumn{2}{|c|}{ Amount $(\mathrm{t})$} & 2.0 & 2.5 \\
\hline & \multirow{4}{*}{$\begin{array}{l}\text { Initial composition } \\
\text { (mass \%) }\end{array}$} & {$[\mathrm{C}]$} & 3.88 & 4.08 \\
\hline & & [Si] & tr. & tr. \\
\hline & & {$[\mathrm{Mn}]$} & 0.27 & 1.44 \\
\hline & & {$[\mathrm{P}]$} & 0.094 & 0.608 \\
\hline & \multicolumn{2}{|c|}{ Initial/ Final temperature (K) } & $1627 / 1804$ & $1654 / 1783$ \\
\hline \multirow{2}{*}{$\begin{array}{l}\text { Material } \\
(\mathrm{kg} / \mathrm{t})\end{array}$} & \multicolumn{2}{|c|}{ Hot metal dephosphorization slag } & 50 & 150 \\
\hline & \multicolumn{2}{|l|}{ Cokes } & 84 & 180 \\
\hline \multicolumn{3}{|c|}{ Top $\mathrm{O}_{2} \quad\left(\mathrm{Nm}^{3} / \mathrm{min}.\right)$} & $1.2 \cdot 3.5$ & $1.3-3.5$ \\
\hline \multicolumn{3}{|c|}{ Bottom Ar Flow rate $\left(\mathrm{Nm}^{3} / \mathrm{min}.\right)$} & 1.0 & 2.0 \\
\hline
\end{tabular}

Table 1. Composition of dephosphorization slag.

\begin{tabular}{|c|c|c|c|c|c|c|c|c|c|c|}
\hline \multirow{2}{*}{$\begin{array}{c}\text { Test } \\
\text { No. }\end{array}$} & \multicolumn{10}{|c|}{ Chemical composition (mass\%) } \\
\cline { 2 - 12 } & $\mathrm{T} . \mathrm{Fe}$ & $\mathrm{FeO}$ & $\mathrm{Fe}_{2} \mathrm{O}_{3}$ & $\mathrm{CaO}$ & $\mathrm{SiO}_{2}$ & $\mathrm{P}_{2} \mathrm{O}_{5}$ & $\mathrm{MnO}$ & $\mathrm{Al}_{2} \mathrm{O}_{3}$ & $\mathrm{MgO}$ & $\mathrm{F}$ \\
\hline Test-1 & 4.21 & 3.45 & 0.52 & 42.09 & 23.43 & 5.12 & 10.17 & 3.6 & 3.56 & 2.52 \\
\hline Test-2 & 6.57 & 5.71 & 2.09 & 37.19 & 20.56 & 7.94 & 13.27 & 4.95 & 3.99 & 1.32 \\
\hline
\end{tabular}




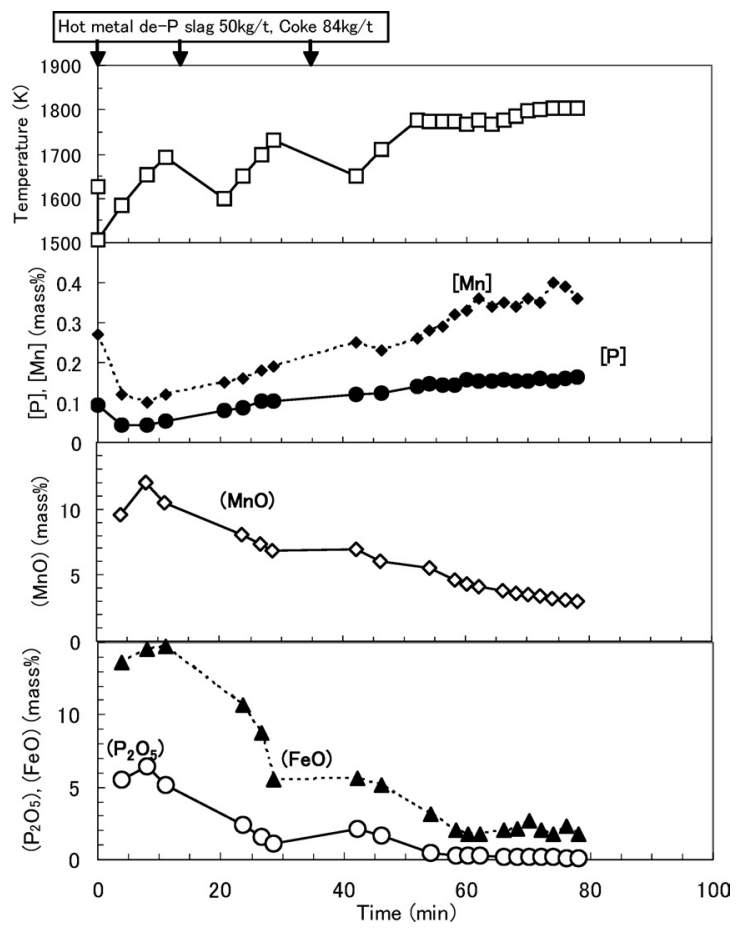

Fig. 3. Behaviors of slag and metal compositions in Test-1.

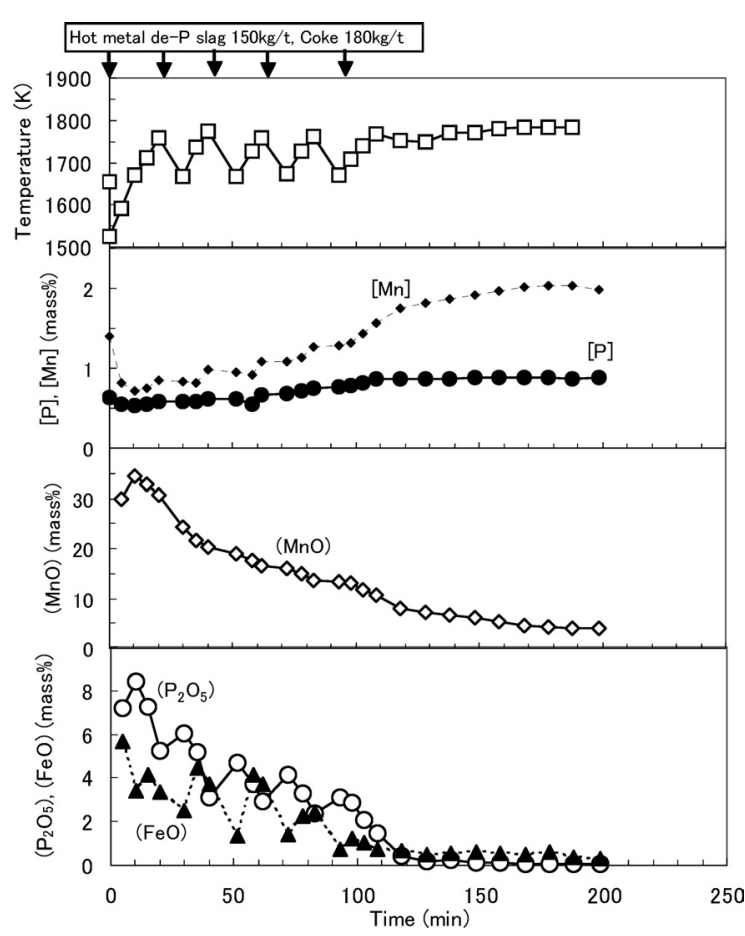

Fig. 4. Behaviors of slag and metal compositions in Test-2.

Also, the amount of phosphorus and manganese in the metal was calculated by the metal amount estimated by $\mathrm{Fe}$ material balance and analysis of [P] and [Mn].

Calculation results of material balance in Test-1 and Test-2 are shown in Fig. 5 and Fig. 6 respectively. The amount of phosphorus and manganese oxide in the slag decreased and the amount of phosphorus and manganese in the metal increased in turn during the reduction. But unknown amount of these elements which occupied about $20 \%$ of total input also existed in these experiments. This is considered to be caused by vaporization of phosphorus and

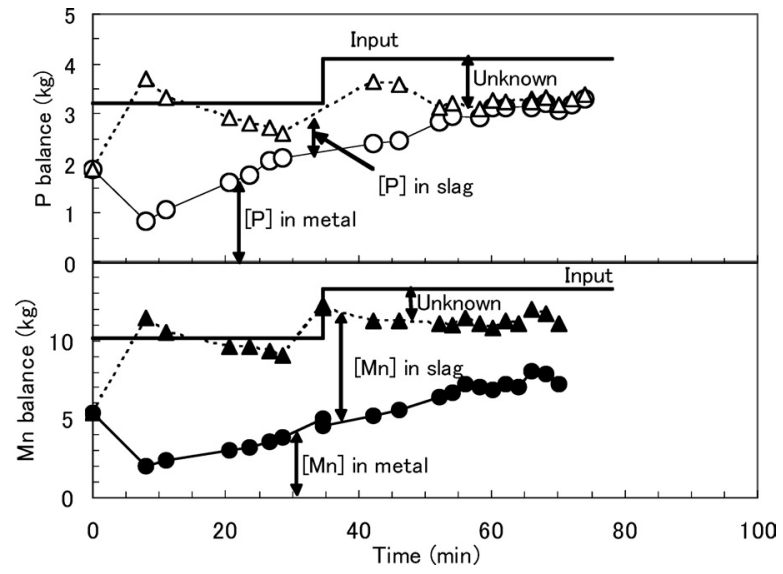

Fig. 5. $\mathrm{P}$ and $\mathrm{Mn}$ balances during the reduction in Test-1.

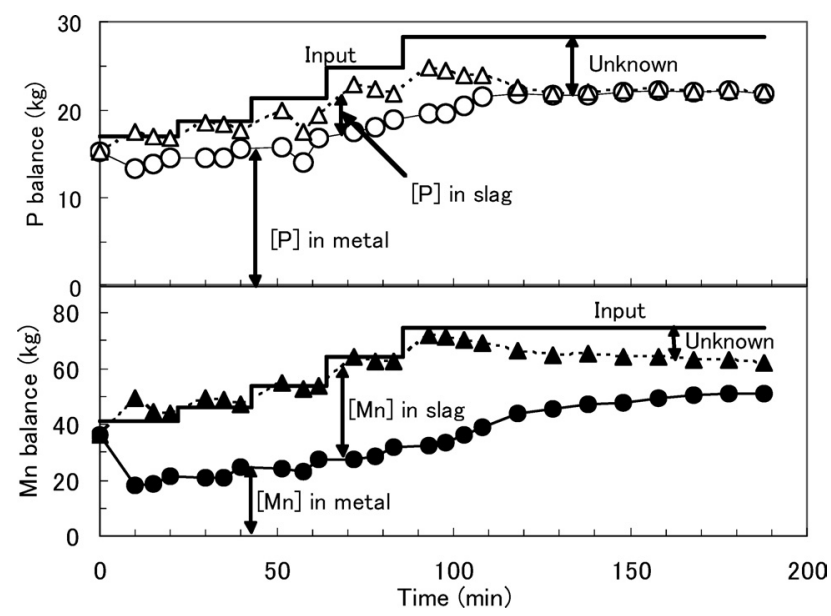

Fig. 6. $\mathrm{P}$ and $\mathrm{Mn}$ balances during the reduction in Test-2.

manganese from reduced metal droplet during reduction as will be mentioned later.

\subsection{Reduction Equilibrium}

In order to discuss the priority of the reduction reactions, an investigation of reduction equilibrium is necessary because reduction of phosphorus oxide, iron oxide and manganese oxide in slag proceeds simultaneously. Reduction equilibrium at slag/metal interface and slag/coke interface must be considered because reduction reaction takes place at both interfaces. At slag/metal interface, each oxide reacts with the balk hot metal. Reduction reactions at slag/metal interface are given by Eqs. (1), (2) and (3). Activity of each oxide which is equilibrated with the balk hot metal is given by Eqs. $(4)^{6)},(5)^{6,7)}$ and (6). ${ }^{7,8)}$ Activity coefficients of carbon, phosphorus and manganese are given by Eqs. (7)$(9),{ }^{9,10)}(11)^{11)}$ and $(13)^{11)}$ respectively:

$$
\begin{array}{r}
{[\mathrm{C}]+(\mathrm{FeO})=\mathrm{CO}+\mathrm{Fe}(\mathrm{l}) \ldots \ldots \ldots} \\
{[\mathrm{C}]+(\mathrm{MnO})=\mathrm{CO}+[\mathrm{Mn}] \ldots \ldots .} \\
5[\mathrm{C}]+\left(\mathrm{P}_{2} \mathrm{O}_{5}\right)=5 \mathrm{CO}+2[\mathrm{P}] \ldots \ldots \ldots \\
\left\{a_{\mathrm{FeO}(\mathrm{l})}\right\}_{[\mathrm{C}]}=\frac{1}{a_{\mathrm{C}}} \cdot 10^{5085.07 / T-4.658}
\end{array}
$$




$$
\begin{aligned}
& \left\{a_{\mathrm{MnO}(1)}\right\}_{[\mathrm{C}]}=\frac{a_{\mathrm{Mn}}}{a_{\mathrm{C}}} \cdot 10^{8379.71 / T-5.8051} \\
& \left\{a_{\mathrm{P}_{2} \mathrm{O}_{5}(1)}\right\}_{[\mathrm{C}]}=\frac{a_{\mathrm{P}}^{2}}{a_{\mathrm{C}}^{5}} \cdot 10^{31046.31 / T-39.077} .
\end{aligned}
$$

$\log f_{\mathrm{C}}=\log f_{\text {C.sat }}+0.027[\text { mass } \% \mathrm{Si}]_{\mathrm{b}}-0.003[\text { mass } \% \mathrm{Mn}]_{\mathrm{b}}$

$$
+0.028[\operatorname{mass} \% \mathrm{P}]_{\mathrm{b}}
$$

$$
\begin{array}{r}
\log f_{\text {C.sat }}=-1.749+\frac{4350}{T}\left\{1+4 \times 10^{-4}(T-1770)\right\} \\
\times N_{\mathrm{C}}\left(2-N_{\mathrm{C}}\right)+\log \left(55.85-43.85 N_{\mathrm{C}}\right) \ldots \ldots \\
\log N_{\mathrm{C}}=-\frac{12.728}{T}+0.7266 \log T-3.049 \ldots \ldots \\
a_{\mathrm{C}}=f_{\mathrm{C}}[\text { mass } \% \mathrm{C}]_{\mathrm{b}} \ldots \ldots \ldots \ldots \ldots \ldots \ldots \ldots \ldots \ldots \ldots \ldots \ldots \ldots \ldots
\end{array}
$$

$$
\begin{aligned}
\log f_{\mathrm{P}}= & 0.126[\text { mass } \% \mathrm{C}]_{\mathrm{b}}+0.099[\mathrm{mass} \% \mathrm{Si}]_{\mathrm{b}} \\
& -0.032[\mathrm{mass} \% \mathrm{Mn}]+0.054[\mathrm{mass} \% \mathrm{P}]_{\mathrm{b}} \\
& +0.034[\mathrm{mass} \% \mathrm{~S}]_{\mathrm{b}} \ldots \ldots \ldots \ldots \ldots \ldots \ldots \ldots \ldots \ldots \ldots \ldots \ldots \ldots \ldots \ldots \ldots \ldots \ldots \ldots
\end{aligned}
$$$$
a_{\mathrm{P}}=f_{\mathrm{P}}[\operatorname{mass} \% \mathrm{P}]_{\mathrm{b}}
$$

$$
\begin{array}{r}
\log f_{\mathrm{Mn}}=-0.0538[\text { mass } \% \mathrm{C}]_{\mathrm{b}}-0.0327[\text { mass } \% \mathrm{Si}]_{\mathrm{b}} \\
-0.06[\text { mass } \% \mathrm{P}]_{\mathrm{b}}-0.048[\text { mass } \% \mathrm{~S}]_{\mathrm{b}} \ldots \ldots \ldots \\
a_{\mathrm{Mn}}=f_{\mathrm{Mn}}[\operatorname{mass} \% \mathrm{Mn}]_{\mathrm{b}} \ldots \ldots \ldots \ldots \ldots \ldots \ldots \ldots \ldots \ldots \ldots \ldots
\end{array}
$$

Also, at slag/coke interface, each oxide reacts with graphite as coke to form the metal droplet. Reduction reactions at slag/coke interface are given by Eqs. (15), (16) and (17). Activity of each oxide which is equilibrated with the metal droplet formed at slag/coke interface is given by Eqs. $(18),{ }^{6,7)}(19)^{6,7)}$ and (20). ${ }^{7,8)}$ Activities of iron and manganese are estimated by assuming that the metal droplet is an ideal solution. The activity coefficient of phosphorus $\left(f_{\mathrm{P}}\right)_{\mathrm{g}}$ is evaluated from the empirical equation, Eq. (21), derived by reading graph of the activity of phosphorus in $\mathrm{Fe}-$ $\mathrm{C}$ melt by Schenck et al. ${ }^{12)}$ Although the graph presented by Schenck et al. covers the range of phosphorus content only less than 5 mass $\%$, Elliot et al. ${ }^{13)}$ reported that the activity coefficient of phosphorus increased gradually in the range of mole fraction less than 0.3 , namely less than about 19 mass \%. Consequently, it may be thought that the estimation of the activity coefficient of phosphorus is possible by extrapolating Eq. (21) to high phosphorus content. The metal droplet generated by the reduction at the slag/coke interface is $\mathrm{Fe}-\mathrm{C}-\mathrm{P}-\mathrm{Mn}$ system. No information is available concerning the activity coefficient of phosphorus in this system, but $\mathrm{Fe}-\mathrm{C}-\mathrm{P}-\mathrm{Mn}$ system is thought to be treated approximately as $\mathrm{Fe}-\mathrm{C}-\mathrm{P}$ system because $\mathrm{Fe}$ and $\mathrm{Mn}$ forms ideal solution. Thus, the activity coefficient of phosphorus in $\mathrm{Fe}-\mathrm{C}-\mathrm{P}-\mathrm{Mn}$ system may be given by Eq. (21). Carbon content in the metal droplet is evaluated by assuming carbon saturation. ${ }^{14)}$

At slag/coke interface, phosphorus, manganese and iron oxides are reduced by graphite to form metal droplets with high phosphorus and manganese contents. No information is available about the composition of metal droplet. So, using both material balance and driving force analysis of each oxide during reduction, composition of metal droplet will be estimated as mentioned later.

$$
\begin{aligned}
& \mathrm{C}_{\text {gr. }}+(\mathrm{FeO})=\mathrm{CO}+\mathrm{Fe}(1) \\
& \mathrm{C}_{\mathrm{gr} .}+(\mathrm{MnO})=\mathrm{CO}+[\mathrm{Mn}] \\
& 5 \mathrm{C}_{\mathrm{gr} .}+\left(\mathrm{P}_{2} \mathrm{O}_{5}\right)=5 \mathrm{CO}+2[\mathrm{P}] \\
& \left\{a_{\mathrm{FeO}(1)}\right\}_{\mathrm{gr} .}=\left(a_{\mathrm{Fe}}\right)_{\mathrm{g}} \cdot 10^{5984.99 / T-6.7370} \text {. } \\
& \left\{a_{\mathrm{MnO}(1)}\right\}_{\mathrm{gr} .}=\left(a_{\mathrm{Mn}}\right)_{\mathrm{g}} \cdot 10^{9279.63 / T-7.884} \\
& \left\{a_{\mathrm{P}_{2} \mathrm{O}_{5}(1)}\right\}_{\text {gr. }}=\left(a_{\mathrm{P}}\right)_{\mathrm{g}}^{2} \cdot 10^{35545.88 / T-49.470} \\
& \log \left(f_{\mathrm{P}}\right)_{\mathrm{g}}=0.1399[\operatorname{mass} \% \mathrm{P}]_{\mathrm{g}}+0.1477[\operatorname{mass} \% \mathrm{C}]_{\mathrm{g}} . . \\
& \left(a_{\mathrm{P}}\right)_{\mathrm{g}}=\left(f_{\mathrm{P}}\right)_{\mathrm{g}}[\mathrm{mass} \% \mathrm{P}]_{\mathrm{g}}
\end{aligned}
$$

In addition, reactions of phosphorus and manganese with iron oxide given by Eqs. (23) and (24) must be considered. Activities of oxides decided by these reactions are given by Eqs. $(25)^{6)}$ and $(26)^{6)}$ :

$$
\begin{aligned}
& {[\mathrm{Mn}]+(\mathrm{FeO})=(\mathrm{MnO})+\mathrm{Fe}(\mathrm{l})} \\
& 2[\mathrm{P}]+5(\mathrm{FeO})=\left(\mathrm{P}_{2} \mathrm{O}_{5}\right)+5 \mathrm{Fe}(\mathrm{l}) \\
& \left\{a_{\mathrm{MnO}(1)}\right\}_{(\mathrm{FeO})}=\left\{a_{\mathrm{FeO}(1)}\right\}_{\mathrm{obs} .} \cdot a_{\mathrm{Mn}} \cdot 10^{3294.64 / T-1.1468} \text {. } \\
& \left\{a_{\mathrm{P}_{2} \mathrm{O}_{5}(1)}\right\}_{(\mathrm{FeO})}=\left\{a_{\mathrm{FeO}(1)}\right\}_{\mathrm{obs} .}^{5} \cdot a_{\mathrm{P}}^{2} \cdot 10^{5620.95 / T-15.7854} \ldots
\end{aligned}
$$

Observed activities calculated from slag compositions were estimated by using the regular solution model. ${ }^{6}$ As shown in Table 1, 1.3 to $2.5 \%$ of fluorine is included in the slag used in the experiments. The fluorine is added as a fluorite and is included in the form of $\mathrm{CaF}_{2}$ in the slag. The effect of fluorine on the activities of phosphorus oxide and iron oxide is not able to consider in the regular solution model. However, in the activity estimation, total $\mathrm{CaO}$ value which includes both $\mathrm{Ca}$ in $\mathrm{CaF}_{2}$ and $\mathrm{CaO}$ was used as $\mathrm{CaO}$ content in the slag. Suito et al. ${ }^{15)}$ pointed out that the effect of $\mathrm{CaF}_{2}$ on the activity coefficient of $\mathrm{P}_{2} \mathrm{O}_{5}$ was the same as $\mathrm{CaO}$. Consequently, by using total $\mathrm{CaO}$ content, the regular solution model may be used for the estimation of the activities of phosphorus oxide in the slag containing fluorine. Also, the the activities of iron oxide may be estimated by using total $\mathrm{CaO}$ content in the regular solution model.

Thus, observed activities calculated from slag compositions by using the regular solution model ${ }^{6)}$ are given by Eqs. (27), (28) and (29). The priority of each reduction reaction was investigated by comparison of equilibrium activities with observed ones mentioned above.

$$
\begin{aligned}
& \left\{a_{\mathrm{FeO}(1)}\right\}_{\mathrm{obs} .} \\
& =\exp \left(\frac{R T \ln \left(X_{\mathrm{FeO}} \cdot \gamma_{\mathrm{FeO}(\mathrm{R} . \mathrm{S} .)}\right)-8540+7.142 T}{R T}\right) \ldots
\end{aligned}
$$




$$
\begin{aligned}
& \left\{a_{\mathrm{MnO}(1)}\right\}_{\text {obs. }} \\
& =\exp \left(\frac{R T \ln \left(X_{\mathrm{MnO}} \cdot \gamma_{\mathrm{MnO}(\text { R.S. })}\right)-86860+51.465 T}{R T}\right) \\
& \left\{a_{\mathrm{P}_{2} \mathrm{O}_{5}(1)}\right\}_{\text {obs. }} \\
& =\exp \left(\frac{2 R T \ln \left(X_{\mathrm{PO}_{2.5}} \cdot \gamma_{\mathrm{PO}_{2.5}(\text { R.S. })}\right)-52720+230.706 T}{R T}\right)
\end{aligned}
$$

Transition of equilibrium activities and observed ones of oxides in Test- 1 and Test- 2 are shown in Figs. 7 and 8 respectively. Activities of oxides equilibrated with carbon in the bulk hot metal were very low. Observed activities of oxides were far larger than equilibrium ones in the whole period of the reduction. In such condition of these experiments, the reduction at slag/metal interface is thought to proceed easily. On the other hand, activities of phosphorus oxide and manganese oxide equilibrated with graphite are thought to be higher than those equilibrated with carbon in the bulk hot metal and slightly smaller than observed activities, because phosphorus and manganese contents in the metal droplet generated at slag/coke interface are estimated to be higher than those in the bulk hot metal as will be mentioned later. However, the reductions of phosphorus oxide and manganese oxide at the slag/coke interface are thought to proceed more nearly to the equilibrium state than at the slag/metal interface.

Also, equilibrium activities of manganese oxide and phosphorus oxide decided by the reaction of manganese and phosphorus with iron oxide, Eqs. (23) and (24), were higher than the observed ones in Test- 1 and Test- 2 as shown in Figs. 7 and 8. The condition of this work is involved in the application range of Eqs. (25) and (26) both in slag composition and in temperature except in low phosphorus oxide region at the last stage of each experiment. So application error is thought to be small. Basically, as the reduction of oxides in slag by carbon in the hot metal and graphite in coke is non equilibrium process, it is not unreasonable that equilibrium activities and observed ones do not correspond. It is thought that the reductions of phosphorus oxide and manganese oxide mainly proceed by carbon in the hot metal and graphite in coke but not mainly proceed by $\mathrm{Fe}$ in the hot metal. So observed activities of manganese oxide and phosphorus oxide were nearer to the equilibrium ones decided by Eqs. (5), (6), (19) and (20) and lower than the equilibrium ones decided by Eqs. (25) and (26).

\subsection{Vaporization of Phosphorus and Manganese}

As mentioned above, about $20 \%$ of added phosphorus and manganese were not detected by the material balance of slag and metal. In order to consider this reason, the vaporization pressure of phosphorus and manganese were estimated. The slag/metal interface and the slag/coke interface are thought to be reaction sites of phosphorus and manganese oxides reduction. As phosphorus and manganese reduced at the slag/metal interface are thought to be absorbed to the metal bath immediately after the reduction,

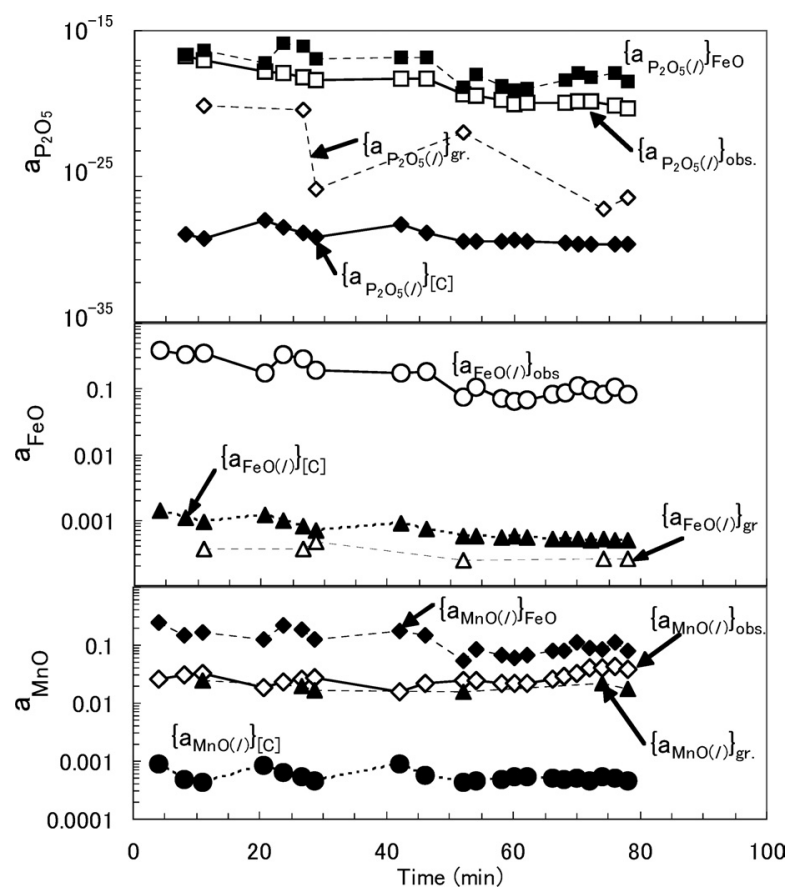

Fig. 7. Behaviors of observed and equilibrium activity of slag components in Test-1.

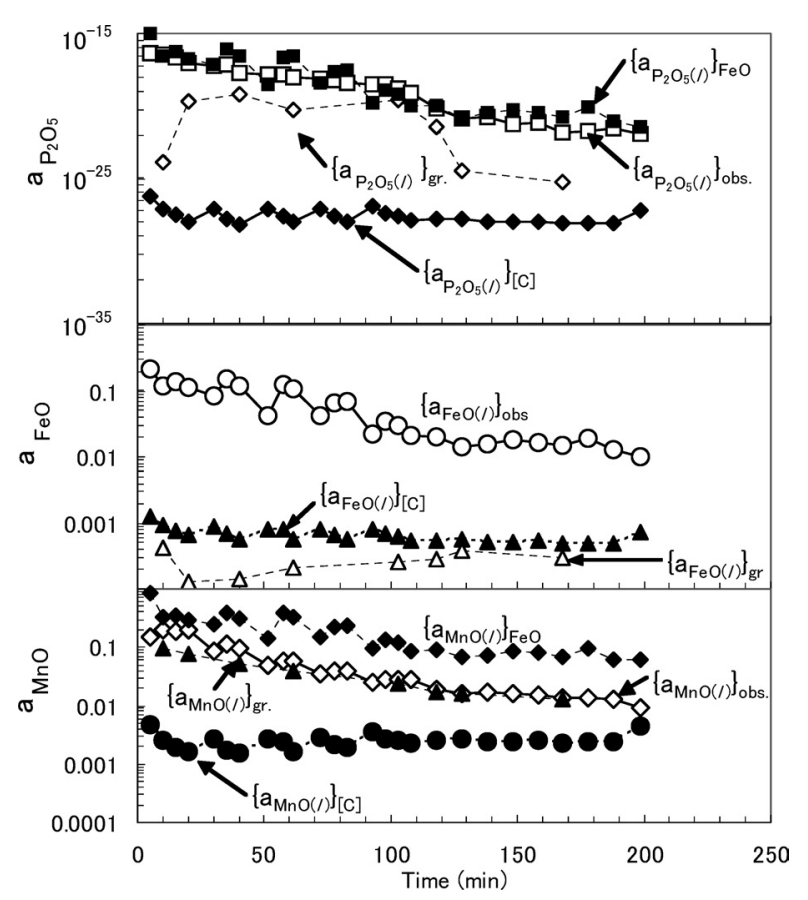

Fig. 8. Behaviors of observed and equilibrium activity of slag components in Test-2.

content of these elements in the metal bath are not higher than 2 mass $\%$. On the other hand, phosphorus and manganese contents in metal droplets generated by the reduction at the slag/coke interface are thought to be very high until the metal droplets are absorbed to the metal bath. From this point of view, phosphorus and manganese contents in metal droplets generated by the reduction at the slag/coke interface were estimated by the change of slag composition during reduction, and possibility of vaporization of these elements was investigated by estimating the vapor pressure. 
The phosphorus and manganese contents in the metal droplets generated by the reduction at the slag/coke interface are estimated by calculating the reduced amount of phosphorus, manganese and iron oxide in the slag in the period of 2 to $10 \mathrm{~min}$ using the estimated slag amount and the analysis of these compositions. The slag amount was estimated by $\mathrm{CaO}$ balance.

In this estimation, it is necessary to consider the difference of phosphorus and manganese contents of reduced metal both at the slag/metal and the slag/coke interfaces. At the slag/metal interface, the driving force of reduction is decided by the equilibrium between slag and bulk metal. At the slag/coke interface, on the other hand, the driving force of reduction is decided by the equilibrium between slag and metal droplet which has higher contents of phosphorus and manganese than bulk metal. Consequently, the driving force of reduction at the slag/coke interface is smaller than at the slag/metal interface and, as a result, phosphorus and manganese contents in metal droplet generated at the slag/coke interface are thought to be lower than those in the metal generated at the slag/metal interface.

Consequently, phosphorus and manganese contents were estimated by considering the difference of driving force of oxide reduction in each interface. Phosphorus and manganese contents of reduced metal at the slag/metal interface are assumed to be the same as calculated ones by the material balance. The reduced amount of phoshorous, manganese and iron in the slag in the period of 2 to $10 \mathrm{~min}$ corresponding slag sampling interval are given by Eqs. (30), (31) and (32):

$$
\begin{array}{r}
W_{\mathrm{Fe}}=\left(W_{\mathrm{s}}\right)_{1} \frac{(\mathrm{mass} \% \mathrm{~T} . \mathrm{Fe})_{1}-(\mathrm{mass} \% \mathrm{M} . \mathrm{Fe})_{1}}{100} \\
-\left(W_{\mathrm{s}}\right)_{2} \frac{(\mathrm{mass} \% \mathrm{~T} . \mathrm{Fe})_{2}-(\mathrm{mass} \% \mathrm{M} . \mathrm{Fe})_{2}}{100} \ldots \ldots .(30) \\
W_{\mathrm{P}}=0.437\left\{\left(W_{\mathrm{s}}\right)_{1} \frac{\left(\mathrm{mass} \% \mathrm{P}_{2} \mathrm{O}_{5}\right)_{1}}{100}-\left(W_{\mathrm{s}}\right)_{2} \frac{\left(\mathrm{mass} \% \mathrm{P}_{2} \mathrm{O}_{5}\right)_{2}}{100}\right\} \\
W_{\mathrm{Mn}}=0.774\left\{\left(W_{\mathrm{s}}\right)_{1} \frac{(\mathrm{mass} \% \mathrm{MnO})_{1}}{100}-\left(W_{\mathrm{s}}\right)_{2} \frac{(\mathrm{mass} \% \mathrm{MnO})_{2}}{100}\right\}
\end{array}
$$

Here, $W_{\mathrm{s}}$ is the amount of slag estimated by $\mathrm{CaO}$ balance and is given by Eq. (33):

$$
W_{\mathrm{s}}=\frac{100 W_{\mathrm{CaO}}}{(\mathrm{mass} \% \mathrm{CaO})}
$$

Subscripts ' 1 ' and ' 2 ' mean the initial state and final state of the time interval respectively. The compositions of metal generated by the reduction at the slag/metal interface are estimated by assuming the mixing of these reduced elements and melting of carbon into the metal to saturated content $^{14)}$ and are given by Eqs. (34)-(36):

$$
[\operatorname{mass} \% \mathrm{P}]_{\mathrm{r}}=\left(1-\frac{[\operatorname{mass} \% \mathrm{C}]_{\mathrm{r}}}{100}\right) \frac{W_{\mathrm{P}}}{100\left(W_{\mathrm{Fe}}+W_{\mathrm{P}}+W_{\mathrm{Mn}}\right)}
$$

$$
[\operatorname{mass} \% \mathrm{Mn}]_{\mathrm{r}}=\left(1-\frac{[\mathrm{mass} \% \mathrm{C}]_{\mathrm{r}}}{100}\right) \frac{W_{\mathrm{Mn}}}{100\left(W_{\mathrm{Fe}}+W_{\mathrm{P}}+W_{\mathrm{Mn}}\right)}
$$

$$
\begin{aligned}
{[\operatorname{mass} \% \mathrm{C}]_{\mathrm{r}}=} & 1.34+2.54 \times 10^{-3}(T-273) \\
& -0.33[\operatorname{mass} \% \mathrm{P}]_{\mathrm{r}}+0.03[\operatorname{mass} \% \mathrm{Mn}]_{\mathrm{r}} \ldots
\end{aligned}
$$

Phosphorus and manganese contents in the metal generated by the reduction at the slag/metal interface calculated above are higher than those in the bulk metal. However, as the amount of the metal generated by the reduction at the slag/metal interface is far smaller than that of the bulk metal, phosphorus and manganese contents in the metal near to the slag/metal interface are thought to be the same as contents in the bulk metal by agitation. Consequently, the driving force of oxide reduction in the slag/metal interface is estimated as the difference of observed activity and one equilibrated with metal bath. On the other hand, the driving force of oxide reduction in the slag/coke interface is estimated as the difference of observed oxide activity and one equilibrated with graphite in coke, phosphorus and manganese in metal droplet.

In the calculation of equilibrium oxide activity with graphite in coke, phosphorus and manganese in metal droplet, it is necessary to know the metal droplet composition generated in the interface. A tentative value $[\operatorname{mass} \% \mathrm{P}]_{\mathrm{g}}$, $[\text { mass } \% \mathrm{Mn}]_{\mathrm{g}}$ are set as the metal droplet composition in this aim, and by using this tentative value, the driving force of oxide reduction in the slag/coke interface is estimated and the ratio of the driving force of oxide reduction in the slag/coke interface to that in the slag/metal interface is calculated. The metal droplet composition is finally estimated by a try and error method which make the ratio equal the ratio of the tentative value to the metal composition estimated by the material balance. Thus, phosphorus and manganese contents in metal droplet are given as $[\operatorname{mass} \% \mathrm{P}]_{\mathrm{g}}$ and $[\mathrm{mass} \% \mathrm{Mn}]_{\mathrm{g}}$ which satisfy Eqs. (37) and (38).

$$
\begin{gathered}
\frac{[\text { mass } \% \mathrm{P}]_{\mathrm{g}}}{[\mathrm{mass} \% \mathrm{P}]_{\mathrm{r}}}=\frac{\left\{a_{\mathrm{P}_{2} \mathrm{O}_{5}(1)}\right\}_{\text {obs. }}-\left\{a_{\mathrm{P}_{2} \mathrm{O}_{5}(1)}\right\}_{\text {gr. }}}{\left\{a_{\mathrm{P}_{2} \mathrm{O}_{5}(1)}\right\}_{\text {obs. }}-\left\{a_{\mathrm{P}_{2} \mathrm{O}_{5}(1)}\right\}_{[\mathrm{C}]}} . \\
\frac{[\mathrm{mass} \% \mathrm{Mn}]_{\mathrm{g}}}{[\mathrm{mass} \% \mathrm{Mn}]_{\mathrm{r}}}=\frac{\left\{a_{\mathrm{MnO}(1)}\right\}_{\text {obs. }}-\left\{a_{\mathrm{P}_{2} \mathrm{O}_{5}(1)}\right\}_{\text {gr. }}}{\left\{a_{\mathrm{P}_{2} \mathrm{O}_{5}(1)}\right\}_{\text {obs. }}-\left\{a_{\mathrm{P}_{2} \mathrm{O}_{5}(1)}\right\}_{[\mathrm{C}]}}
\end{gathered}
$$

The estimated phosphorus and manganese contents in metal droplets generated by the reduction at the slag/coke interface are shown and compared with the contents estimated by the material balance in Figs. 9 and 10. The estimated content of manganese in the metal droplets by above procedures was lower than that estimated by the material balance. On the other hand, the estimated content of phosphorus in metal droplets is almost the same as that estimated by the material balance. 


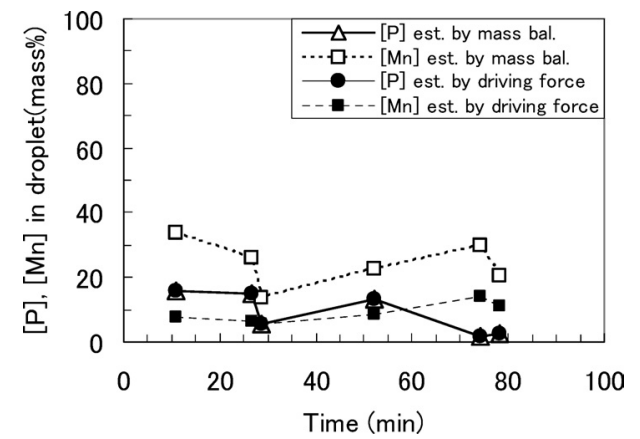

Fig. 9. Behaviors of the estimated metal droplet compositions in Test-1.

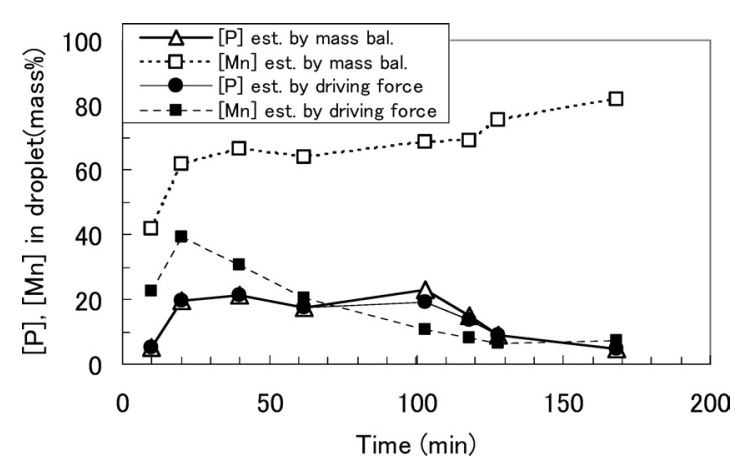

Fig. 10. Behaviors of the estimated metal droplet compositions in Test-2.

By above investigation, it is clarified that the estimated content of manganese in the metal droplet generated at the slag/coke interface is lower than that in the metal generated at the slag/metal interface because the decrease of driving force of manganese oxide reduction at the slag/coke interface by the increase of manganese content is large. Consequently, the consideration of driving force of reduction is necessary for the estimation of manganese content in the metal droplet generated at the slag/coke interface. On the other hand, the estimated content of phosphorus in metal droplets is almost the same as that in the metal generated at the slag/metal interface because the decrease of driving force of phosphorus oxide reduction at the slag/coke interface by the increase of phosphorus content is relatively smaller than in case of manganese oxide reduction.

Phosphorus content was estimated to be 16 mass $\%$ and manganese content was estimated to be 11 mass $\%$ in maximum in Test-1. Also, phosphorus content was estimated to be $21 \mathrm{mass} \%$ and manganese content was estimated to be $39 \%$ in maximum in Test-2.

The solution of phosphorus to the molten iron is given by Eq. (39). ${ }^{16)}$ By using the equilibrium constant of this reaction given by Eq. (40), vapor pressure of phosphorus in equilibrium with the molten iron is given by Eq. (41):

$$
\begin{aligned}
& \frac{1}{2} P_{2}(\mathrm{~g})=[\mathrm{P}] \\
& \Delta G_{0}=-157700+5.4 T(\mathrm{~J} / \mathrm{mol}) \\
& \log K=\log \frac{a_{\mathrm{P}}}{p_{\mathrm{P}_{2}}^{1 / 2}}=\frac{8236.6}{T}-0.282
\end{aligned}
$$

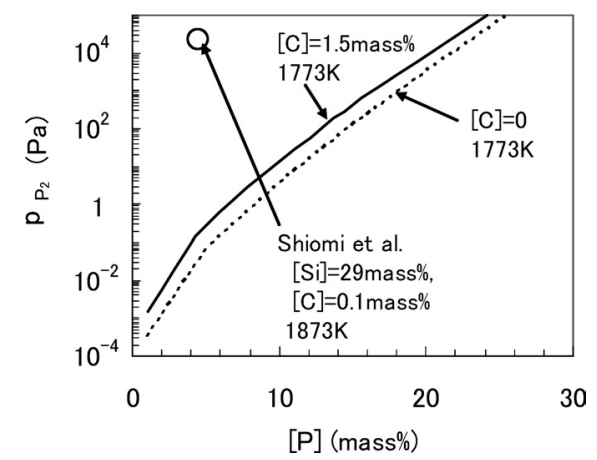

Fig. 11. Relationship between $[\mathrm{P}]$ and the vapor pressure of phosphorous.

$$
\begin{aligned}
& p_{\mathrm{P}_{2}}=a_{\mathrm{P}}^{2} \cdot 10^{-16473.2 / T+0.564} \text {. } \\
& a_{\mathrm{P}}=f_{\mathrm{P}}[\% \mathrm{P}]
\end{aligned}
$$

The activity coefficient of phosphorus $f_{\mathrm{P}}$ is evaluated from the empirical equation, Eq. (21) as mentioned above. Relationship between phosphorus content in metal droplet and vapor presssure of phosphorus estimated by Eqs. (21), (41) and (42) is shown in Fig. 11. Vapor presssure of phosphorus in metal droplet is estimated to be 1 to $10^{4} \mathrm{~Pa}$ from Fig. 11, because phosphorus content in metal droplet is estimated to be 4 to 21 mass\% from Figs. 9 and 10 .

Shiomi et al. ${ }^{4}$ studied about the possibility of vaporization removal of phosphorus from $\mathrm{Fe}-0.1 \% \mathrm{C}-29 \mathrm{mass} \% \mathrm{Si}-$ $4.45 \mathrm{mass} \% \mathrm{P}$ molten iron and proved the removal was possible in $\mathrm{Ar}$ gas stream. However, the phosphorus vapor pressure of this molten iron was not estimated in the study. Consequently, the phosphorus vapor pressure of this molten iron will be estimated below and will be compared to the estimated one of the metal droplet generated by the reduction at the slag/coke interface in this study to consider the possibility of phosphorus vaporization from the droplet.

Shiomi et al. $^{4)}$ derived Eq. (43) as interaction parameter $e_{\mathrm{P}}^{\mathrm{Si}}$ in $\mathrm{Fe}-\mathrm{Si}-\mathrm{P}$ melt. The carbon content was very low in the molten iron in the study of Shiomi et al. The activity coefficient of phosphorus $f_{\mathrm{P}}$ at the carbon content of zero was evaluated from the empirical equation, Eq. (44), derived by reading graph of the activity of phosphorus in $\mathrm{Fe}-\mathrm{C}$ melt by Schenck et al. ${ }^{12)}$ to estimate the phosphorus vapor pressure of molten iron in the study of Shiomi et al. By considering the interaction parameter estimated in Eq. (43), the activity coefficient of phosphorus in $\mathrm{Fe}-\mathrm{Si}-\mathrm{P}$ melt is given by Eq. (45):

$$
\begin{array}{r}
e_{\mathrm{P}}^{\mathrm{Si}}=0.118-0.000930[\text { mass } \% \mathrm{Si}] \quad(1873 \mathrm{~K}) \ldots \ldots \\
\log f_{\mathrm{P}}=0.1160\left[\operatorname{mass}_{0} \mathrm{P}\right]
\end{array}
$$

$\log f_{\mathrm{P}}=0.1160[$ mass $\% \mathrm{P}]$

$$
+(0.118-0.000930[\operatorname{mass} \% \mathrm{Si}])[\operatorname{mass} \% \mathrm{Si}] \ldots
$$

The vapor pressure of phosphorus in $\mathrm{Fe}-\mathrm{Si}-\mathrm{P}$ melt of the study by Shiomi et al. estimated by using Eqs. (41), (42) and (45) is also plotted in Fig. 11. The vapor pressure of phosphorus in $\mathrm{Fe}-0.1 \% \mathrm{C}-29 \mathrm{mass} \% \mathrm{Si}-4.45 \mathrm{mass} \% \mathrm{P}$ melt of the study by Shiomi et al. was estimated as $22700 \mathrm{~Pa}$. Shiomi et al. pointed out that dephosphorization of molten iron with this composition could easily proceed by the va- 
porization of phosphorus in Ar gas stream as mentioned above and that the vaporization rate of phosphorus was determined by mass transfer of $\mathrm{P}_{2}$ in the gas phase and was proportional to the vapor pressure of phosphorus. Also, the vapor pressure of phosphorus in droplet is estimated to be 1 to $10^{4} \mathrm{~Pa}$ as mentioned above which is $1 / 2$ in maximum of that in $\mathrm{Fe}-\mathrm{Si}-\mathrm{P}$ melt of the study by Shiomi et al. Consequently, the vaporization of phosphorus from the droplet may occur in the same way as in the study by Shiomi et al. though the vaporization rate may be smaller than that in the study by Shiomi et al.

On the other hand, the phosphorus content in metal bath is not higher than $1 \%$ and the estimated vapor pressure of phosphorus in the metal bath is about $10^{-3} \mathrm{~Pa}$. This value is smaller by the order of 3 to 6 than that of droplet and is smaller by the order of 7 than that of $\mathrm{Fe}-0.1 \% \mathrm{C}-$ 29 mass $\% \mathrm{Si}-4.45$ mass $\% \mathrm{P}$ molten iron at $1873 \mathrm{~K}$ in the study of Shiomi et al. Consequently, the vaporization of phosphorus from metal bath may be negligibly small and unknown part of phosphorus in material balance is seemed to be caused by the vaporization of phosphorus from the droplet.

The vaporization of manganese from pure manganese melt shown by Eq. (46) is given by Eqs. (47) ${ }^{17)}$ and (48). ${ }^{17)}$ $\mathrm{Fe}-\mathrm{Mn}$ melt is thought to behave as an ideal solution. Also, the effect of phosphorus and carbon on the activity coefficient of manganese is thought to be small. Thus, the vapor pressure of manganese in iron melt is given by Eq. (49) by assuming that the activity of manganese in iron melt is proportional to the mole fraction.

$$
\begin{aligned}
& \operatorname{Mn}(1)=\operatorname{Mn}(g) \\
& \log p_{\text {Mn (1) }}=-\frac{14520}{T}-3.02 \log T+19.24 \mathrm{mmHg} \ldots . \\
& p_{\mathrm{Mn}(\mathrm{l})}=132.89 \times 10^{-14520 / \mathrm{T}-3.02 \log T+19.24} \mathrm{~Pa} \ldots \\
& p_{\mathrm{Fe}-\mathrm{Mn}}=132.89 X_{\mathrm{Mn}} \cdot 10^{-14520 / T-3.02 \log T+19.24} \mathrm{~Pa}
\end{aligned}
$$

The vapor pressure of manganese in iron melt is calculated by Eq. (49) and the result is plotted against mass\% of manganese as shown in Fig. 12. By the same manner as in the evaluation of the phosphorus vapor pressure, from the estimated manganese content in the droplet of 6 to $39 \%$ in Figs. 9 and 10, the vapor pressure of manganese is estimated as $10^{2}$ to $10^{3} \mathrm{~Pa}$ by Fig. 12 . This value of the vapor pressure of manganese is almost the same order as that of phos-

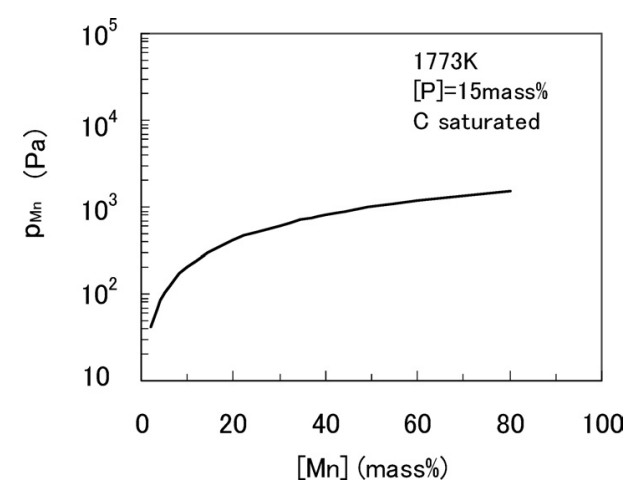

Fig. 12. Relationship between $[\mathrm{Mn}]$ and the vapor pressure of manganese. phorus estimated above. Also, Ward ${ }^{18)}$ pointed out that the vaporization rate of manganese was determined by mass transfer of manganese in the gas phase and was proportional to the vapor pressure of manganese. Thus, manganese in the droplet may vaporize in the same way as phosphorus.

On the other hand, the manganese content in metal bath is not higher than $2 \%$ and the estimated vapor pressure of manganese in the metal bath is about $40 \mathrm{~Pa}$ from Fig. 12. This value is smaller by the order of 1 than that of the droplet. Consequently, the vaporization of manganese from metal bath may be smaller than that from the metal droplet and unknown part of manganese in material balance is seemed to be caused mainly by the vaporization of manganese from the droplet.

\section{Conclusions}

(1) Dephosphorization slag and coke as the reduction agent and the heat source were added to the hot metal in the converter and oxygen was blown through the top lance. During the blowing, the reduction of $\left(\mathrm{P}_{2} \mathrm{O}_{5}\right),(\mathrm{FeO})$ and $(\mathrm{MnO})$ in the slag proceeded simultaneously. Activities of oxides equilibrated with carbon in the bulk hot metal were very low. Observed activities of oxides were far larger than equilibrium ones in the whole period of the reduction. On the other hand, activities of phosphorus oxide and manganese oxide equilibrated with graphite are thought to be higher than those equilibrated with carbon in the bulk hot metal and slightly smaller than observed activities, because phosphorus and manganese contents in the metal droplet generated at slag/coke interface are estimated to be higher than those in the bulk hot metal. However, the reductions of phosphorus oxide and manganese oxide at the slag/coke interface are thought to proceed more nearly to the equilibrium state than at the slag/metal interface.

(2) The amount of phosphorus and manganese oxide in the slag decreased and the amount of phosphorus and manganese in the metal increased in turn during the reduction. The unknown amount of these elements which occupied about $20 \%$ of total input also existed. By the estimation of vaporization pressure of phosphorus and manganese, unknown parts of phosphorus and manganese in material balance are seemed to be mainly caused by the vaporization of phosphorus and manganese from the droplets generated by the reduction at the slag/coke interface.

\section{Nomenclature}

$\left\{a_{\mathrm{FeO}(1)}\right\}_{[\mathrm{C}]},\left\{a_{\mathrm{MnO}(\mathrm{l})}\right\}_{[\mathrm{C}]},\left\{a_{\mathrm{P}_{2} \mathrm{O}_{5}(1)}\right\}_{[\mathrm{C}]}$ : Activities in equilibrium with carbon in hot metal

$\left\{a_{\mathrm{FeO}(1)}\right\}_{\text {gr. }},\left\{a_{\mathrm{MnO}(1)}\right\}_{\text {gr. }},\left\{a_{\mathrm{P}_{2} \mathrm{O}_{5}(1)}\right\}_{\text {gr. }}$ : Activities in equilibrium with graphite as coke

$\left\{a_{\mathrm{MnO}(1)}\right\}_{(\mathrm{FeO})},\left\{a_{\mathrm{P}_{2} \mathrm{O}_{5}(1)}\right\}_{(\mathrm{FeO})}$ : Activities in equilibrium with $\mathrm{FeO}$ in slag

$\left\{a_{\mathrm{FeO}(1)}\right\}_{\text {obs. }},\left\{a_{\mathrm{MnO}(1)}\right\}_{\text {obs., }},\left\{a_{\mathrm{P}_{2} \mathrm{O}_{5}(1)}\right\}_{\text {obs. }}$ : Activities calculated from slag composition by regular solution model

$T: \quad$ Temperarure (K)

$X$ : Mole fraction

$\gamma_{\mathrm{FeO}(\mathrm{R} . \mathrm{S} .)}, \gamma_{\mathrm{MnO}(\mathrm{R} . \mathrm{S} .)}, \gamma_{\mathrm{PO}_{2.5}(\text { R.S.) }}:$ Activity coefficients calculated by regular solution model

$a_{\mathrm{C}}, a_{\mathrm{Mn}}, a_{\mathrm{P}}$ : Activities of elements in the bulk hot 
metal

$\left(a_{\mathrm{Fe}}\right)_{\mathrm{g}},\left(a_{\mathrm{Mn}}\right)_{\mathrm{g}},\left(a_{\mathrm{P}}\right)_{\mathrm{g}}$ : Activities of elements in the metal droplet

$f_{\mathrm{C}}, f_{\mathrm{P}}, f_{\mathrm{Mn}}$ : Activity coefficients of elements in the bulk hot metal

$\left(f_{\mathrm{P}}\right)_{\mathrm{g}}$ : Activity coefficient of phosphorus in the metal droplet

$[\operatorname{mass} \% \mathrm{C}]_{\mathrm{b}},[\operatorname{mass} \% \mathrm{Si}]_{\mathrm{b}}, \quad[\mathrm{mass} \% \mathrm{Mn}]_{\mathrm{b}}, \quad[\mathrm{mass} \% \mathrm{P}]_{\mathrm{b}}$, $[\operatorname{mass} \% \mathrm{~S}]_{\mathrm{b}}$ : Contents in the bulk hot metal

$[\operatorname{mass} \% \mathrm{C}]_{\mathrm{r}},[\operatorname{mass} \% \mathrm{Mn}]_{\mathrm{r}}, \quad[\operatorname{mass} \% \mathrm{P}]_{\mathrm{r}}$ : Contents in the metal generated at the slag/metal interface

$[\operatorname{mass} \% \mathrm{C}]_{\mathrm{g}},[\operatorname{mass} \% \mathrm{Mn}]_{\mathrm{g}}, \quad[\operatorname{mass} \% \mathrm{P}]_{\mathrm{g}}$ : Contents in the metal droplet

$W_{\mathrm{s}}$ : Weight of slag

$W_{\text {Cao }}$ : Weight of added $\mathrm{CaO}$

(mass\%T.Fe): Total Fe content in the slag

(mass\%M.Fe): Metallic Fe content in the slag

$\left(\operatorname{mass} \% \mathrm{P}_{2} \mathrm{O}_{5}\right),(\operatorname{mass} \% \mathrm{MnO}),(\operatorname{mass} \% \mathrm{CaO})$ : Contents in the slag

\section{REFERENCES}

1) T. Matsuo, I. Yamazaki, S. Masuda, K. Yoshida, A. Mori and S. Fukagawa: Proc. of 73rd Steelmaking Conf., ISS, Warrendale, PA,
(1990), 115 .

2) T. Ueki, K. Fujiwara, N. Yamada, S. Saeki and T. Tanioku: Proc. of 10th Japan-China Symp. on Science and Technology of Iron and Steel, ISIJ, Tokyo, (2004), 116.

3) H. J. Li, H. Suito and M. Tokuda: ISIJ Int., 35 (1995), 1079.

4) S. Shiomi, N. Sano and Y. Matsushita: Tetsu-to-Hagané, 63 (1977), 1520.

5) M. Ishikawa, M. Tsuda, Y. Shirota, S. Anesaki and K. Marukawa: Proc. of Int. Conf. on Steel and Society, ISIJ, Tokyo, (2000), 289.

6) S. Ban-Ya: ISIJ Int., 33 (1993), 2.

7) S. Ban-Ya and S. Matoba: Tetsu-to-Hagané, 48 (1962), 925.

8) E. T. Turkdogan and J. Pearson: J. Iron Steel Inst., 175 (1953), 398.

9) A. Rist and J. Chipman: Rev. Met., Mem., 53 (1956), 796.

10) F. Neumann and H. Schenck: Arch. Eisenhüttenwes., 30 (1959), 477.

11) Steelmaking Data Source Book, ed. by The Japan Society for the Promotion of Science, The 19th Commitieeon Steelmaking, Tokyo, (1984).

12) H. Schenck, E. Steinmety and R. Gohlke: Arch. Eisenhüttenwes, 37 (1966), 775; 39 (1968), 109.

13) J. F. Elliot, M. Gleiser and V. Ramakrishna: Thermochemistry for Steelmaking, Vol. 2, Addison-Wesley Publishing Company Inc., Reading, (1963), 519.

14) J. Chipman: Trans. Am. Soc. Met., 44 (1952), 1215.

15) H. Suito and R. Inoue: Tetsu-to-Hagané, 68 (1982), 1541.

16) M. Yamamoto, K. Yamada, L. L. Meshkov and E. Katoh: Tetsu-toHagané, 66 (1980), 2032.

17) O. Kubachewski and C. B. Alcock: Metallurgical Thermochemistry, 5th Ed., Pergamon Press, Oxford, (1979), 366.

18) R. G. Ward: J. Iron Steel Inst., 201 (1963), 221. 